\title{
Action potential bursts in central snail neurons elicited by paeonol: roles of ionic currents
}

\author{
Yi-hung CHEN ${ }^{1}$, Pei-lin LIN $^{2}$, Hui-yu HSU ${ }^{1}$, Ya-ting WU ${ }^{1}$, Han-yin YANG ${ }^{3}$, Dah-yuu LU ${ }^{4}$, Shiang-suo HUANG ${ }^{5}$, Ching-liang \\ HSIEH ${ }^{1}$, Jaung-geng $\operatorname{LIN}^{3, *}$ \\ ${ }^{1}$ Graduate Institute of Acupuncture Science, College of Chinese Medicine, China Medical University, Taichung, Taiwan, China; ${ }^{2}$ Depart- \\ ment of Anesthesiology, National Taiwan University Hospital, Taipei, Taiwan, China; ${ }^{3}$ Graduate Institute of Chinese Medical Science, \\ College of Chinese Medicine, China Medical University, Taichung, Taiwan, China; ${ }^{4}$ Graduate Institute of Neural and Cognitive Sciences, \\ China Medical University, Taichung, Taiwan, China; ${ }^{5}$ Department of Pharmacology and Institute of Medicine, College of Medicine, \\ Chung Shan Medical University, Taichung, Taiwan, China
}

\begin{abstract}
Aim: To investigate the effects of 2'-hydroxy-4'-methoxyacetophenone (paeonol) on the electrophysiological behavior of a central neuron (right parietal 4; RP4) of the giant African snail (Achatina fulica Ferussac).

Methods: Intracellular recordings and the two-electrode voltage clamp method were used to study the effects of paeonol on the RP4 neuron.

Results: The RP4 neuron generated spontaneous action potentials. Bath application of paeonol at a concentration of $\geq 500 \mu m o l / L$ reversibly elicited action potential bursts in a concentration-dependent manner. Immersing the neurons in $\mathrm{Co}^{2+}$-substituted $\mathrm{Ca}^{2+}$-free solution did not block paeonol-elicited bursting. Pretreatment with the protein kinase A (PKA) inhibitor KT-5720 or the protein kinase C (PKC) inhibitor Ro 31-8220 did not affect the action potential bursts. Voltage-clamp studies revealed that paeonol at a concentration of $500 \mu \mathrm{mol} / \mathrm{L}$ had no remarkable effects on the total inward currents, whereas paeonol decreased the delayed rectifying $\mathrm{K}^{+}$current $\left(I_{\mathrm{KD}}\right)$ and the fast-inactivating $\mathrm{K}^{+}$current $\left(I_{\mathrm{A}}\right)$. Application of 4-aminopyridine (4-AP $5 \mathrm{mmol} / \mathrm{L}$ ), an inhibitor of $I_{A}$, or charybdotoxin 250 $\mathrm{nmol} / \mathrm{L}$, an inhibitor of the $\mathrm{Ca}^{2+}$-activated $\mathrm{K}^{+}$current $\left(I_{\mathrm{K}(\mathrm{Ca})}\right)$, failed to elicit action potential bursts, whereas tetraethylammonium chloride (TEA $50 \mathrm{mmol} / \mathrm{L}$ ), an $I_{K D}$ blocker, successfully elicited action potential bursts. At a lower concentration of $5 \mathrm{mmol} / \mathrm{L}$, TEA facilitated the induction of action potential bursts elicited by paeonol.

Conclusion: Paeonol elicited a bursting firing pattern of action potentials in the RP4 neuron and this activity relates closely to the inhibitory effects of paeonol on the $I_{\mathrm{KD}}$.
\end{abstract}

Keywords: paeonol; neuron; snail; action potential bursts; fast-inactivating $\mathrm{K}^{+}$current; delayed rectifying current

Acta Pharmacologica Sinica (2010) 31: 1553-1563; doi: 10.1038/aps.2010.156; published online 1 Nov 2010

\section{Introduction}

The Chinese have used herbs to treat a wide variety of medical ailments for several thousand years. Moutan cortex, the root bark of Paeonia suffruticosa Andrews, has long been used for its antipyretic and anti-inflammatory effects in traditional Chinese medicine ${ }^{[1,2]}$. One of the major components of Moutan cortex is 2'-hydroxy-4'-methoxyacetophenone (paeonol), which has been reported to possess analgesic, antipyretic and antibacterial properties as well as anti-inflammatory and antioxidant activities and an ability to suppress ADP or collageninduced human blood platelet aggregation ${ }^{[1,3,4]}$.

\footnotetext{
* To whom correspondence should be addressed.

E-mail jglin@mail.cmu.edu.tw

Received 2010-05-31 Accepted 2010-08-06
}

Recent pharmacological experiments have shown that paeonol protects against reperfusion-induced myocardial damage $^{[5]}$. Paeonol has also been reported to block the L-type calcium current in cardiac myocytes, thereby decreasing the excitability of cardiac tissue ${ }^{[6]}$. In a recent study carried out in guinea pig ventricular myocytes using patch-clamp techniques, paeonol decreased the action potential upstroke phase, an action associated with the blockade of the voltage-gated fast sodium channel ${ }^{[7]}$.

Other research indicates that paeonol has neuroprotective effects. For example, paeonol has been shown to protect rat neurons from oxygen-glucose deprivation-induced injury by alleviating morphological damage and increasing neuron viability $^{[8]}$. Paeonol has ameliorated neuronal damage in both the hippocampus and temporal cortex in D-galactose-treated 
mice $^{[9]}$. These results suggest that paeonol possesses antiaging properties and may have potential in the treatment of neurodegenerative diseases. However, scant evidence exists as to the effects of paeonol on neuronal excitability.

The central nervous system of the gastropod snail contains large, identifiable neurons with known pharmacological profiles and synaptic inputs. The size, accessibility and relative simplicity of the molluscan neuronal network makes it an ideal in vitro preparation for electrophysiological and neuropharmacological studies ${ }^{[10-12]}$. Identifiable neurons in the ganglia can undergo repeated investigations into drug-related effects on the same neuron. Snail ganglia contain many identifiable neurotransmitters and receptors, and their neurons are used for biological studies ${ }^{[11,13,14]}$. In our previous studies, CNS stimulants, including d-amphetamine, cocaine and methamphetamine, elicited in vitro action potential bursts in the central right parietal 4 (RP4) neuron of the African snail Achatina fulica Ferussac ${ }^{[13,15-17]}$.

Few studies have examined the effects of paeonol on neuronal excitability. The present study aimed to determine the effects of paeonol on membrane potentials and ionic currents in the central RP4 neuron using the conventional two-electrode voltage clamp technique.

\section{Materials and methods}

Experiments were performed on identified central RP4 neurons from the subesophageal ganglia of the African snail Achatina fulica Ferussac. The ganglia were pinned to a Sylgardcoated perfusion chamber base (volume $=2 \mathrm{~mL}$ ) and removed from the connective tissue sheath to allow easy identification and penetration by microelectrodes ${ }^{[13,16,17]}$.

Intracellular recordings were made with a Gene clamp 500 amplifier (Axon Instruments, Foster City, CA, USA). Membrane potentials were recorded with microelectrodes (5-6 M $\Omega$ ) filled with $3 \mathrm{~mol} / \mathrm{L}$ potassium chloride $(\mathrm{KCl})$. The experimental chamber was perfused with the control solution, ie, (in mmol/L) $\mathrm{NaCl}$ (85), $\mathrm{KCl}(4), \mathrm{CaCl}_{2}$ (8), $\mathrm{MgCl}_{2}$ (7), and Tris$\mathrm{HCl}(10)$ at $\mathrm{pH} 7.6$, at a room temperature of $23-24{ }^{\circ} \mathrm{C}$ with a perfusion speed of $8 \mathrm{~mL} / \mathrm{min}$. Neurons were studied only if the negativity of their resting membrane potentials (RMPs) exceeded $-50 \mathrm{mV}$, the time constant was around 5-8 $\mathrm{ms}$ and the rate of rise of the action potentials was around $5-8 \mathrm{~V} / \mathrm{s}^{[18]}$.

The ionic currents of the central snail neurons were measured using the two-electrode voltage clamp method. Two microelectrodes were inserted into the neuron for current injection and voltage clamp studies. The recording electrode (5-6 M $\Omega$ ) and current injection electrode (1-5 M 2 ) were filled with $3 \mathrm{~mol} / \mathrm{L} \mathrm{KCl}$. All potentials and currents were recorded on tape via a digitalizing unit (Digidata 1440, Axon Instruments) and analyzed using pCLAMP software.

$\mathrm{Na}^{+}$-free solution was used to measure the fast-inactivating $\mathrm{K}^{+}$current $\left(I_{\mathrm{A}}\right)$. The currents were elicited by $200 \mathrm{~ms}$ test potentials of $-60,-50,-40$, and $-30 \mathrm{mV}$ from a holding potential of $-100 \mathrm{mV}^{[19]}$. A P/4 leak subtraction subpulse routine supplied by the pCLAMP software was used to measure the $I_{\mathrm{A}}$.

For measuring the $I_{\mathrm{KD}}, \mathrm{Na}^{+}$-free and $\mathrm{Co}^{2+}$-substituted $\mathrm{Ca}^{2+}$ - free solutions were used to remove $\mathrm{Ca}^{2+}$ currents $\left(I_{\mathrm{Ca}}\right), \mathrm{Na}^{+}$ currents $\left(I_{\mathrm{Na}}\right)$ and the $\mathrm{Ca}^{2+}$-activated $\mathrm{K}^{+}$current $\left(I_{\mathrm{K}(\mathrm{Ca})}\right)$. RP4 neuron currents were elicited with 500-ms-long voltage clamp steps from a holding potential of $-60 \mathrm{mV}$ to test potentials between -70 and $+50 \mathrm{mV}$ at intervals of $10 \mathrm{mV}$. The potential recording and current injection electrodes were filled with 3 $\mathrm{mol} / \mathrm{L} \mathrm{KCl}$ to measure both types of $\mathrm{K}^{+}$current.

The ganglia were perfused with the following solutions: (a) physiological solution; (b) $\mathrm{Na}^{+}$-free solution: equimolar amounts $(85 \mathrm{mmol} / \mathrm{L})$ of Tris were added to replace $\mathrm{Na}^{+}$ions; (c) $\mathrm{Co}^{2+}$-substituted $\mathrm{Ca}^{2+}$-free solution: equimolar amounts $(8 \mathrm{mmol} / \mathrm{L})$ of $\mathrm{Co}^{2+}$ were added to replace $\mathrm{Ca}^{2+}$ ions; and (d) $\mathrm{Na}^{+}$-free and $\mathrm{Co}^{2+}$-substituted $\mathrm{Ca}^{2+}$-free solution: equimolar amounts of Tris $(85 \mathrm{mmol} / \mathrm{L})$ and $\mathrm{Co}^{2+}(8 \mathrm{mmol} / \mathrm{L})$ were added to replace $\mathrm{Na}^{+}$and $\mathrm{Ca}^{2+}$ ions, respectively. The tetraethylammonium chloride (TEA)-containing solution was prepared by replacing equimolar quantities of $\mathrm{NaCl}$ or Tris-Cl with TEA ${ }^{[20]}$.

Paeonol, 4-aminopyridine (4-AP), TEA, KT-5720, Ro 31-8220 and charybdotoxin were purchased from the Sigma Chemical Company (St Louis, MO, USA). All drug stocks were made with double-distilled water, except for KT-5720 and Ro 31-8220, which were prepared in dimethyl sulfoxide (DMSO), and paeonol, which was prepared in ethanol. The presence of DMSO $(\leq 0.1 \%)$ and ethanol $(\leq 1 \%)$ did not affect the RMPs, amplitude or frequency of the spontaneous firing of action potentials in the RP4 neuron.

Tests of significance regarding any differences between the amplitude and frequency of the action potentials, RMPs and currents post-treatment compared with the pre-drug controls were determined by the Student's paired $t$-test. Differences were considered significant at $P<0.05$.

\section{Results}

Effects of extracellular application of paeonol on spontaneous action potentials of the RP4 neuron

The RMP, amplitude and frequency of spontaneously generated action potentials of the identified RP4 neuron are shown in Table 1. The electrical characteristics of the RP4 neuron were similar to those detailed in a previous report ${ }^{[15]}$.

The effects of paeonol $(150 \mu \mathrm{mol} / \mathrm{L}, 500 \mu \mathrm{mol} / \mathrm{L}$, and 1.5 $\mathrm{mmol} / \mathrm{L}$ ) on the spontaneous firing action potentials of the RP4 neuron are shown in Figure 1 and Table 1. At a concentration of $150 \mu \mathrm{mol} / \mathrm{L}$, paeonol did not alter the action potential firing pattern. As shown in Table 1, at 20 min after extracellular perfusion of paeonol $(150 \mu \mathrm{mol} / \mathrm{L})$, the frequency of spontaneously firing action potentials and the RMP remained unchanged. No action potential bursts were observed even after $1 \mathrm{~h}$ of incubation. However, higher concentrations of paeonol did change the action potential firing pattern. Twenty minutes after extracellular perfusion of paeonol $(500 \mu \mathrm{mol} / \mathrm{L})$, the firing pattern changed from regularly spaced single spikes to one in which bursts of between 2 and 10 action potentials were separated by large hyperpolarizations of the membrane potentials (up to $9 \mathrm{mV}$ ) that lasted for 5-15 s each. The RMP, action potential amplitude and bursting frequency and the 
Table 1. Effects of paeonol, Ro 31-8220, KT-5720, $\mathrm{Co}^{2+}$-substituted $\mathrm{Ca}^{2+}$-free solution, 4-AP, TEA, and charybdotoxin on the resting membrane potential, amplitude and frequency of spontaneously generated action potentials of RP4 neurons, and effects of KT-5720, Ro 31-8220, Co ${ }^{2+}$-substituted Ca ${ }^{2+}$ free solution and TEA on paeonol-elicited action potential bursts. Values are expressed as the mean \pm SEM. ( $n$ being the number of neurons tested). ${ }^{\mathrm{b}} \mathrm{P}<0.05$ vs paeonol $(500 \mu \mathrm{mol} / \mathrm{L})$-elicited action potential bursts. ${ }^{\mathrm{e}} \mathrm{P}<0.05$ vs the data in physiological solution (control).

\begin{tabular}{|c|c|c|c|c|c|c|c|}
\hline Variable & & $n$ & $\mathrm{RMP}(\mathrm{mV})$ & $\begin{array}{l}\text { Amplitude of } \\
\text { action potential } \\
(\mathrm{mV})\end{array}$ & $\begin{array}{l}\text { Frequency of } \\
\text { single spikes } \\
\text { (pulse/min) }\end{array}$ & $\begin{array}{c}\text { Frequency of } \\
\text { bursts } \\
\text { (burst/min) }\end{array}$ & $\begin{array}{l}\text { Number of } \\
\text { action } \\
\text { potential/ } \\
\text { burst }\end{array}$ \\
\hline \multirow[t]{2}{*}{ Paeonol } & Control & 7 & $-57.7 \pm 1.8$ & $85.1 \pm 3.3$ & $50.1 \pm 11.2$ & & \\
\hline & Paeonol $(150 \mu \mathrm{mol} / \mathrm{L})$ & 4 & $-58.5 \pm 2.7$ & $86.1 \pm 6.9$ & $47.3 \pm 11.8$ & & \\
\hline \multirow[t]{4}{*}{ Ro 31-8220+Paeonol } & Control & 5 & $-57.0 \pm 1.1$ & $96.9 \pm 2.1$ & $28.5 \pm 5.0$ & & \\
\hline & Ro 31-8220 (20 بmol/L) & 4 & $-57.7 \pm 1.2$ & $98.8 \pm 2.2$ & $30.0 \pm 6.7$ & & \\
\hline & Ro $31-8220(10 \mu \mathrm{mol} / \mathrm{L})+$ & 3 & $-54.0 \pm 2.3$ & $100.3 \pm 4.5$ & & $7.0 \pm 1.0$ & $4.5 \pm 2.5$ \\
\hline & Paeonol $(500 \mu \mathrm{mol} / \mathrm{L})$ & & & & & & \\
\hline KT-5720+Paeonol & Paeonol (500 $\mu \mathrm{mol} / \mathrm{L})$ & & & & & & \\
\hline \multirow[t]{3}{*}{ Paeonol in $\mathrm{Ca}^{2+}$-free } & Control & 6 & $-63.0 \pm 2.1$ & $98.2 \pm 3.2$ & $26.2 \pm 4.9$ & & \\
\hline & $\mathrm{Ca}^{2+}$-free & 3 & $-49.8 \pm 1.3^{b}$ & $65.7 \pm 3.5^{\mathrm{e}}$ & $22.7 \pm 5.4$ & & \\
\hline & $\begin{array}{l}\text { Paeonol }(500 \mu \mathrm{mol} / \mathrm{L}) \text { in } \\
\mathrm{Ca}^{2+} \text {-free }\end{array}$ & 3 & $-58.3 \pm 1.5$ & $73.5 \pm 5.3^{\mathrm{e}}$ & & $2.7 \pm 1.2^{\mathrm{e}}$ & $17.3 \pm 5.3^{\mathrm{e}}$ \\
\hline \multirow[t]{4}{*}{ Paeonol+TEA } & Control & 3 & $-59.3 \pm 3.3$ & $82.3 \pm 5.2$ & $51.3 \pm 5.3$ & & \\
\hline & TEA (5 mmol/L) & 4 & $-57.5 \pm 1.6$ & $86.0 \pm 3.2$ & $29.5 \pm 3.0^{\mathrm{e}}$ & & \\
\hline & Paeonol $(150 \mu \mathrm{mol} / \mathrm{L})+$ & 3 & $-56.3 \pm 0.7$ & $92.7 \pm 5.6$ & & $14.7 \pm 6.7$ & $3.7 \pm 0.9$ \\
\hline & TEA (5 mmol/L) & & & & & & \\
\hline Charybdotoxin & Charybdotoxin (250 nmol/L) & 3 & $-57.6 \pm 1.2$ & $88.7 \pm 3.2$ & $39.3 \pm 1.5$ & & \\
\hline
\end{tabular}

number of action potentials for each burst are shown in Table 1. These effects of paeonol continued throughout its application (for up to $3 \mathrm{~h}$ ).

At the highest concentration of $1.5 \mathrm{mmol} / \mathrm{L}$, paeonol enhanced the pattern of action potential bursts. The membrane potential underwent a phasic depolarization followed by a sustained depolarization. The number of action potentials for each burst was increased compared with those for the bursts elicited by paeonol $500 \mu \mathrm{mol} / \mathrm{L}$ (Table 1 and Figure 1). After 30 min of continuous washing, the spontaneously generated spikes of the central neuron returned to control levels.

Effects of $\mathrm{Co}^{2+}$-substituted $\mathrm{Ca}^{2+}$-free solution on paeonol-elicited potential changes of the RP4 neuron
To test the effects of $\mathrm{Co}^{2+}$-substituted $\mathrm{Ca}^{2+}$-free solution on paeonol-elicited changes in action potential bursts, the RP4 neuron underwent 30 min of treatment with $\mathrm{Co}^{2+}$-substituted $\mathrm{Ca}^{2+}$-free solution alone (Figure 2A2) or in combination with paeonol (Figure 2B2). $\mathrm{Co}^{2+}$-substituted $\mathrm{Ca}^{2+}$-free solution decreased both the RMP and the amplitude of action potentials (Table 1). No action potential bursts were elicited (Figure 2A2).

In contrast, perfusion with the $\mathrm{Co}^{2+}$-substituted $\mathrm{Ca}^{2+}$-free solution containing paeonol $(500 \mu \mathrm{mol} / \mathrm{L})$ elicited action potential bursts (Figure 2B2 and Table 1). The RMP and the amplitude of action potentials were decreased, as shown in Table 1. The number of action potentials for each burst was higher, and the frequency of bursts lower, compared with the 
1

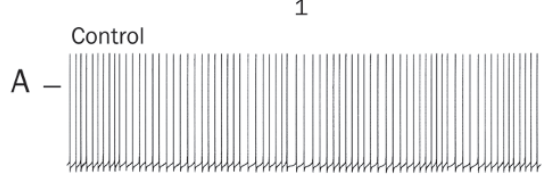

Paeonol (150 $\mu \mathrm{mol} / \mathrm{L})$

$B$

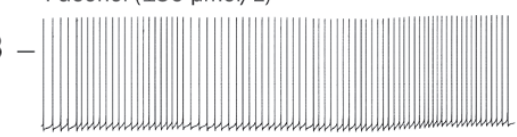

Paeonol (500 $\mu \mathrm{mol} / \mathrm{L})$

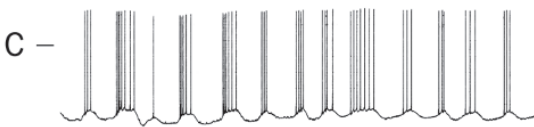

Paeonol (1.5 mmol/L)

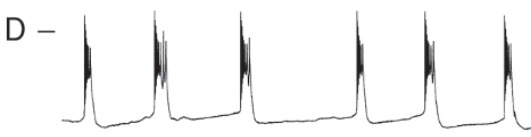

Wash

E

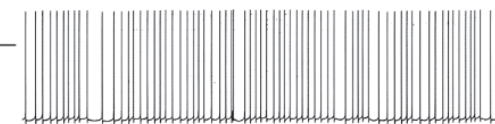

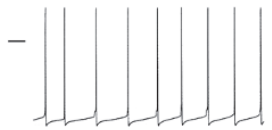
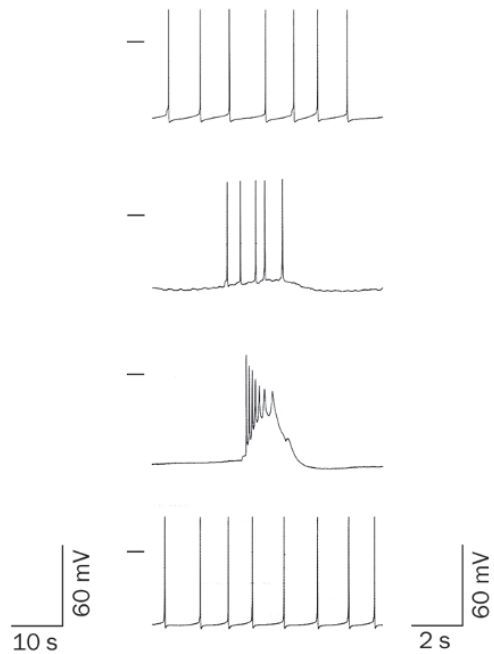
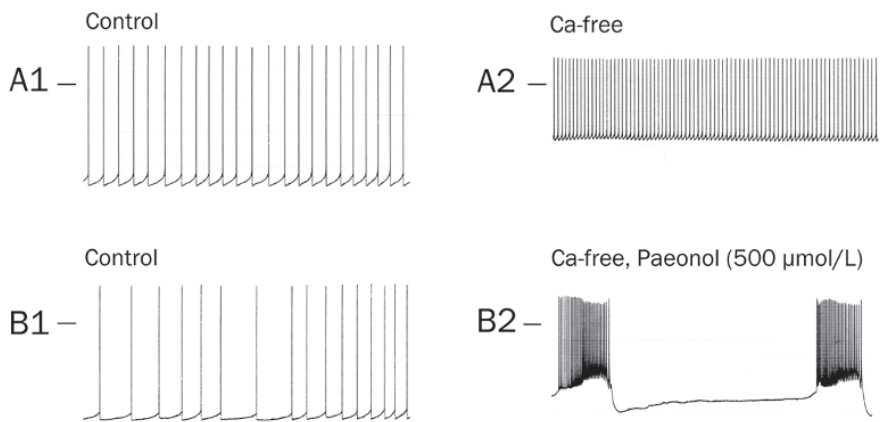

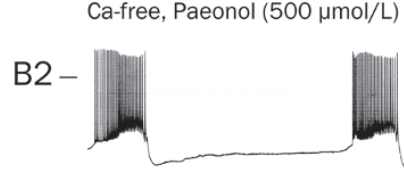

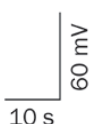

Figure 1. Effects of paeonol on the RP4 neuron. A, B, C, D, and $E$ were recorded from the same neuron. $A 1$ : Control; the neuron shows spontaneous firing of action potentials. B1, C1, and D1: Membrane potentials recorded 20 min after the administration of paeonol (150, 500 and $1500 \mu \mathrm{mol} / \mathrm{L})$, respectively. E1: Membrane potentials measured at $30 \mathrm{~min}$ after the washing off of paeonol from D1. A2, B2, C2, D2, and E2: Expanded pictures showing individual action potentials related to A1, B1, C1, D1, and $\mathrm{E} 1$, respectively. The horizontal bar on the upper left side indicates the membrane potential at $0 \mathrm{mV}$. Notably, action potential bursts were not elicited by paeonol at 150 $\mu \mathrm{mol} / \mathrm{L}$ but were reversibly elicited at concentrations of $500 \mu \mathrm{mol} / \mathrm{L}$ and $1.5 \mathrm{mmol} / \mathrm{L}$. bursting elicited by paeonol at $500 \mu \mathrm{mol} / \mathrm{L}$ in normal physiological solution.

The removal of extracellular calcium ions did not abolish the paeonol $(500 \mu \mathrm{mol} / \mathrm{L})$-induced bursting pattern of action potentials, but it reduced the action potential amplitudes.

\section{Effects of a PKA inhibitor on paeonol-elicited potential changes of the RP4 neuron}

We then sought to determine whether the cAMP-protein kinase A (PKA) signaling pathway is implicated in the generation of paeonol-elicited action potential bursts. As shown in Table 1 and Figure 3B, after 40 min of incubation with the PKA inhibitor KT-5720 $(10 \mu \mathrm{mol} / \mathrm{L})^{[21]}$, the frequency of the spontaneous action potentials, the RMP and the amplitude of the action potentials did not differ from those of the control RP4 neuron.

As mentioned earlier, paeonol $(500 \mu \mathrm{mol} / \mathrm{L})$ elicited action potential bursts in the RP4 neuron. When KT-5720 10 $\mu \mathrm{mol} / \mathrm{L}-$ pretreated RP4 neurons were further incubated with paeonol $(500 \mu \mathrm{mol} / \mathrm{L})$ for $20 \mathrm{~min}$, action potential bursts were elicited, as shown in Table 1 and Figure 3C.

Pretreatment with KT-5720 failed to prevent paeonol-elicited action potential bursts.

\section{Effects of a PKC inhibitor on paeonol-elicited potential changes of the RP4 neuron}

To determine whether protein kinase $\mathrm{C}$ (PKC) is involved in the generation of action potential bursts elicited by paeonol, we tested the effects of PKC inhibition with Ro 31-8220 (20 $\mu \mathrm{mol} / \mathrm{L})^{[22]}$. After a 40-min incubation, the RMP, amplitude and frequency of single spikes in the RP4 neuron were not significantly different from values obtained from neurons in normal physiological solution (Table 1 and Figure 3G). Further incubation of Ro 31-8220-pretreated RP4 neurons with paeonol $(500 \mu \mathrm{mol} / \mathrm{L})$ for $20 \mathrm{~min}$ resulted in action potential bursts (Table 1 and Figure $3 \mathrm{H}$ ).

Pretreatment with Ro 31-8220 failed to abolish paeonolgenerated action potential bursts. 

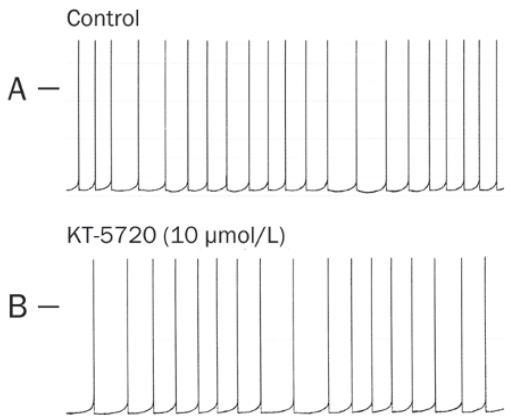

KT-5720 (10 $\mu \mathrm{mol} / \mathrm{L})+$ Paeonol $(500 \mu \mathrm{mol} / \mathrm{L})$
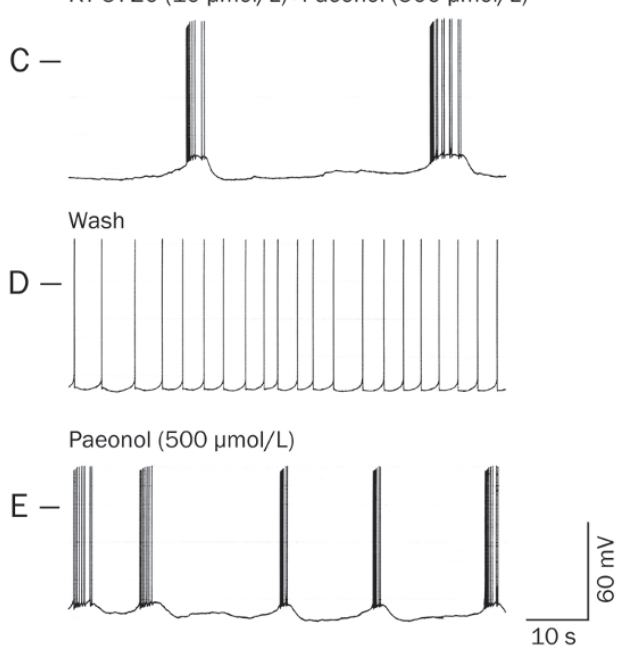
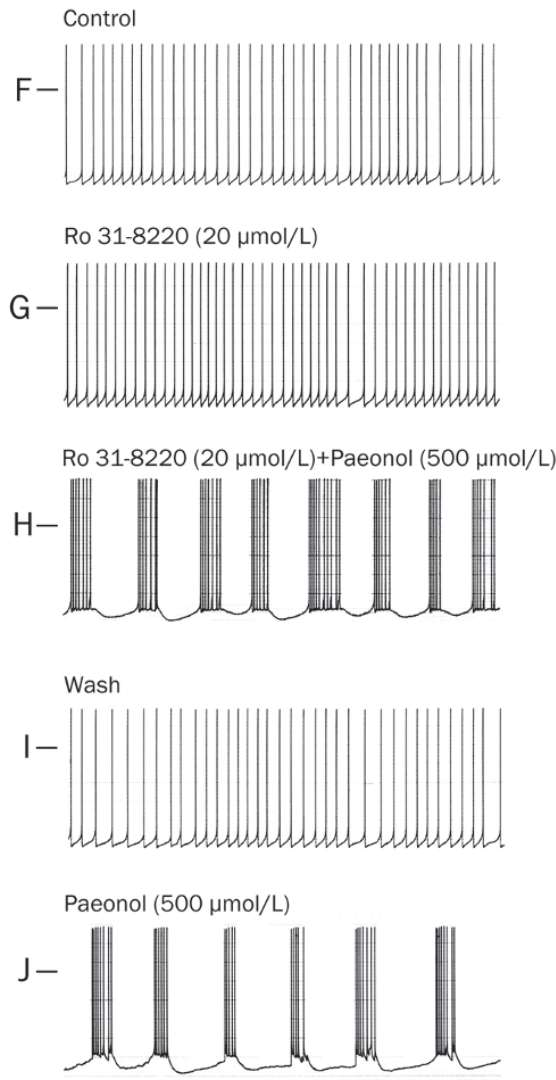

Figure 3. Effects of KT-5720 $(10 \mu \mathrm{mol} / \mathrm{L}$; A-E) and Ro 31-8220 (20 $\mu \mathrm{mol} / \mathrm{L} ; \mathrm{F}-\mathrm{J})$ on paeonol-elicited action potential bursts in the RP4 neuron. A, B, C, D, and E were recorded from the same neuron, while $F, G, H, I$, and $J$ were recorded from another. $A$ and $F$ : Controls; spontaneous action potentials. B and G: Potentials at 40 min after perfusion with KT-5720 (10 $\mu \mathrm{mol} / \mathrm{L})$ and Ro 31-8220 (20 $\mu \mathrm{mol} / \mathrm{L})$, respectively. $\mathrm{C}$ and $\mathrm{H}$ : Potentials at 20 min after further incubation of the neuron with paeonol $(500 \mu \mathrm{mol} / \mathrm{L})$ plus KT-5720 (10 $\mu \mathrm{mol} / \mathrm{L})$ and paeonol $(500 \mu \mathrm{mol} / \mathrm{L})$ plus Ro 31-8220 (20 $\mu \mathrm{mol} / \mathrm{L})$, respectively. D and I: Potentials at 30 min after washing from $\mathrm{C}$ and $\mathrm{H}$, respectively. $\mathrm{E}$ and $\mathrm{J}$ : Potentials at 20 min after incubation of the neuron with paeonol $(500 \mu \mathrm{mol} / \mathrm{L})$ from $\mathrm{D}$ and I, respectively. The horizontal bar on the upper left side indicates the membrane potential at $0 \mathrm{mV}$. Note that paeonol elicited action potential bursts in the presence of KT$5720(10 \mu \mathrm{mol} / \mathrm{L})$ and also Ro 31-8220 (20 $\mu \mathrm{mol} / \mathrm{L})$.

\section{Effects of paeonol on the fast ionic currents of the RP4 neuron} The fast ionic currents of the RP4 neuron clamped at $70 \mathrm{~ms}$ durations are shown in Figure 4 . The membrane potentials were held at $-60 \mathrm{mV}$ and stepped to the testing potentials of $-50,-40,-30,-20,-10,0,10,20$, and $30 \mathrm{mV}$ in 70-ms-long durations. The total inward currents observed in various voltage clamping command steps are shown in Figure 4A. The relationships between the peak inward currents and the test potentials are shown in Figure 4B. The inward current was obvious when the potential was stepped to positive levels that exceeded $-40 \mathrm{mV}$. The maximum peak inward current was observed after voltage stepping to test potentials between $-20 \mathrm{mV}$ and $-10 \mathrm{mV}$. As shown in our previous study, the removal of either extracellular $\mathrm{Na}^{+}$ions or $\mathrm{Ca}^{2+}$ ions decreased the amplitude of the total inward currents ${ }^{[13,23]}$. Both the $I_{\mathrm{Ca}}$ and the $I_{\mathrm{Na}}$ contributed to the total inward currents of the RP4 neuron. As shown in Figure 4B, paeonol $(500 \mu \mathrm{mol} / \mathrm{L})$ did not significantly decrease the fast inward currents in a series of voltage steps.

\section{Effects of paeonol on the $I_{A}$ current}

Measurement of the $I_{\mathrm{A}}$ followed Thompson's method ${ }^{[19]}$. Currents were elicited by $200 \mathrm{~ms}$ test potentials of $-60 \mathrm{mV},-50,-40$, and $-30 \mathrm{mV}$ from a holding potential of $-100 \mathrm{mV}$. An example of the $I_{\mathrm{A}}$ current is shown in Figure 5; the $I_{\mathrm{A}}$ current was completely abolished if 4-AP was applied to the $\mathrm{Na}^{+}$-free solution for 20 min (Figure 5F).
As shown in Figure 5, perfusion of neurons for $20 \mathrm{~min}$ with paeonol $(150 \mu \mathrm{mol} / \mathrm{L})$ did not affect the peak amplitude of the $I_{\mathrm{A}}$. However, the $I_{\mathrm{A}}$ was decreased after a $20 \mathrm{~min}$ perfusion with paeonol at higher concentrations of $500 \mu \mathrm{mol} / \mathrm{L}$ and also $1.5 \mathrm{mmol} / \mathrm{L}$ (by $40.0 \% \pm 6.7 \%, n=4$ and $85.7 \% \pm 0.6 \%, n=3$, respectively; at a test potential of $-30 \mathrm{mV}$ ). Paeonol 150 $\mu \mathrm{mol} / \mathrm{L}$ had no effect on the $I_{\mathrm{A}}$, whereas higher concentrations of paeonol $(500 \mu \mathrm{mol} / \mathrm{L}$ and $1.5 \mathrm{mmol} / \mathrm{L})$ successfully decreased the $I_{\mathrm{A}}$.

\section{Effects of paeonol on the steady-state outward $\mathrm{K}^{+}$current of the RP4 neuron}

The steady-state outward current of the RP4 neuron was measured by 500 -ms-long voltage clamp steps in $\mathrm{Na}^{+}$-free and $\mathrm{Co}^{2+}$-substituted $\mathrm{Ca}^{2+}$-free solution (Figure 6A). In this condition, the $I_{\mathrm{A}}$ and delayed rectifying $\mathrm{K}^{+}\left(I_{\mathrm{KD}}\right)$ components of the outward currents were identified by 4-AP and TEA, as in our previous study ${ }^{[13]}$. The amplitude of the outward current at $500 \mathrm{~ms}$ was significantly reduced (by $40.7 \% \pm 3.1 \%, n=3$; at a test potential of $50 \mathrm{mV})$ after perfusion with TEA $(50 \mathrm{mmol} / \mathrm{L})$ for $40 \mathrm{~min}$ (Figure 6B). If 4 -AP ( $5 \mathrm{mmol} / \mathrm{L}$ ) was applied to the bath solution for $20 \mathrm{~min}$, the outward current remained unchanged. The sensitivity of the outward current to TEA indicates that this is a type of $I_{\mathrm{KD}}$. However, there was a sustained residual TEA-insensitive current ${ }^{[13]}$.

The effects of paeonol on the steady-state outward current in $\mathrm{Na}^{+}$-free and $\mathrm{Co}^{2+}$-substituted $\mathrm{Ca}^{2+}$-free solution are shown in 
A

1

Control

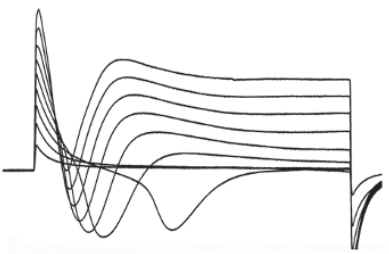

2

Paeonol (500 $\mu \mathrm{mol} / \mathrm{L})$

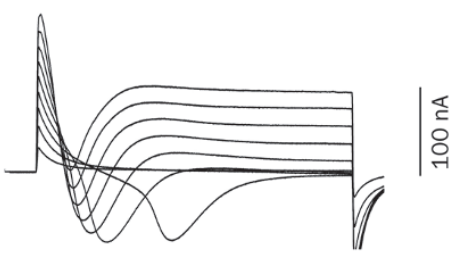

3

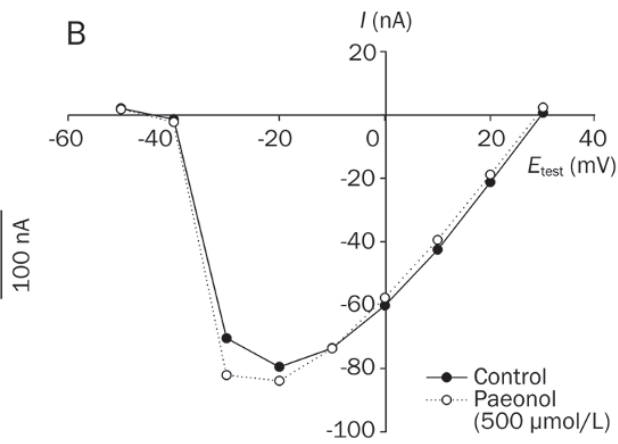

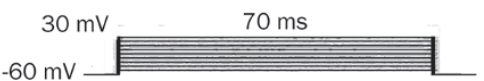

Figure 4. (A) Effects of paeonol on the total inward currents of the RP4 neuron. The membrane currents were elicited from a holding potential of $-60 \mathrm{mV}$ to test potentials of $-50,-40,-30,-20,-10,0,10,20$, and $30 \mathrm{mV}$ of $70-\mathrm{ms}-$ long durations in normal physiological solution. A1: Control; total inward and outward currents recorded in normal physiological solution. A2: Total inward and outward currents recorded at 20 min after incubation with paeonol $(500 \mu \mathrm{mol} / \mathrm{L})$. A3: Voltage step commands. (B) Current-voltage relationships of the peak total inward currents before $(\bullet)$, and at 20 min after $(0)$, paeonol $(500 \mu \mathrm{mol} / \mathrm{L})$ application. Note that paeonol $(500 \mu \mathrm{mol} / \mathrm{L})$ did not decrease the total inward currents.

A Control

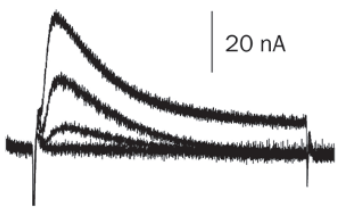

$\mathrm{E}$

Wash
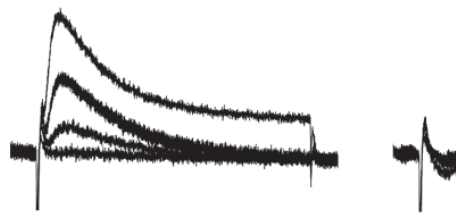

$\mathrm{H}$

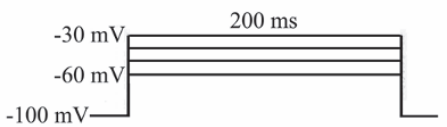

$\mathrm{F}$
$\mathrm{C}$

Paeonol $(500 \mu \mathrm{mol} / \mathrm{L})$
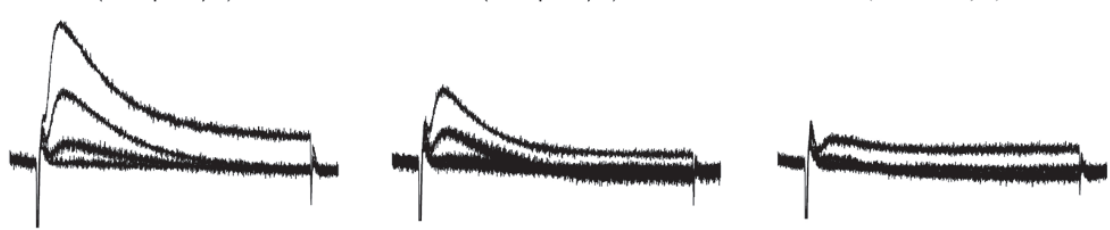

4-AP (5 mmol/L)

G

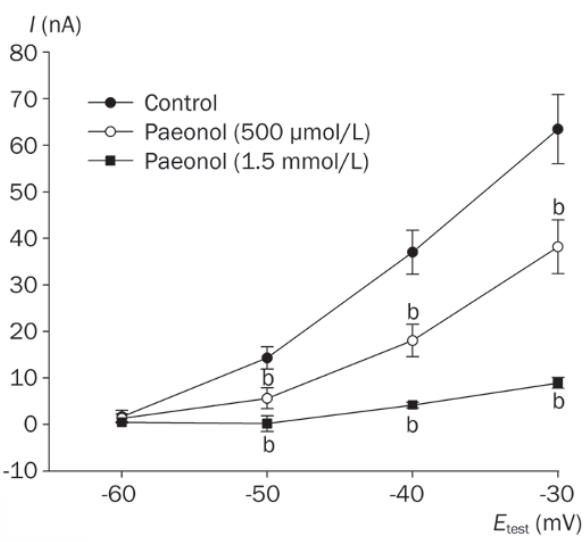

Figure 5. Effects of paeonol on the peak amplitude of the $I_{A}$ current of the RP4 neuron. A: Control $I_{A}$ currents recorded in Na ${ }^{+}$-free solution. B, C, and $\mathrm{D}: I_{\mathrm{A}}$ currents recorded at $20 \mathrm{~min}$ after paeonol $(150 \mu \mathrm{mol} / \mathrm{L})$, paeonol $(500 \mu \mathrm{mol} / \mathrm{L})$ and paeonol $(1.5 \mathrm{mmol} / \mathrm{L})$ administration, respectively. E: $I_{A}$ currents recorded at $30 \mathrm{~min}$ after washing off from D. F: $I_{A}$ currents recorded at 20 min after 4-AP (5 mmol/L) administration from E. G: Currentvoltage relationships of the $I_{A}$ currents before $(\bullet)$ and after paeonol administration at $500 \mu \mathrm{mol} / \mathrm{L}(0)$ and $1.5 \mathrm{mmol} / \mathrm{L}(\mathbf{\bullet})$, respectively. $\mathrm{H}$ : Voltage step commands. Note that paeonol $(500 \mu \mathrm{mol} / \mathrm{L}$ and $1.5 \mathrm{mmol} / \mathrm{L})$ significantly decreased the $I_{\mathrm{A}}$ at 20 min after treatment $\left({ }^{\mathrm{b}} P<0.05 \mathrm{vs}\right.$ control. $\left.n=3-4\right)$.

Figure 6A. The corresponding amplitudes of the steady-state outward currents, as measured at $500 \mathrm{~ms}$ of the outward current, and the steady-state current-voltage $(I-V)$ relationships are shown in Figures $6 \mathrm{C} 1$ and $6 \mathrm{C} 2$. When neurons underwent $20 \mathrm{~min}$ of treatment with paeonol at $150 \mathrm{\mu mol} / \mathrm{L}$, the steadystate outward current was not affected, whereas a 20-min treatment with paeonol at $500 \mu \mathrm{mol} / \mathrm{L}$ significantly decreased the steady-state outward current when subjected to test potentials in the range of $0 \mathrm{mV}$ to $50 \mathrm{mV}$. The current amplitude measured at $500 \mathrm{~ms}$ was reduced by $44.8 \pm 5.2 \mathrm{nA}$ (by $18.2 \% \pm 1.8 \%$ vs controls, $P<0.05, n=5)$ at a test potential of 50 $\mathrm{mV}$. A further 20 -min treatment with paeonol at $1.5 \mathrm{mmol} / \mathrm{L}$ 


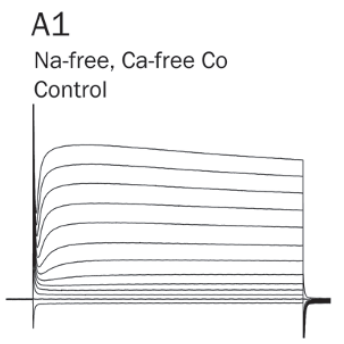

B1

Na-free, Ca-free Co

TEA (50 mmol/L)

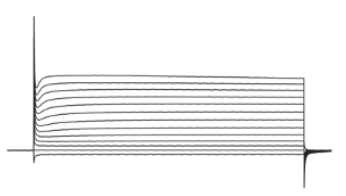

A2

Na-free, Ca-free Co

Paeonol $(150 \mu \mathrm{mol} / \mathrm{L})$

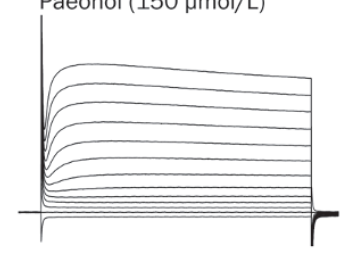

A3

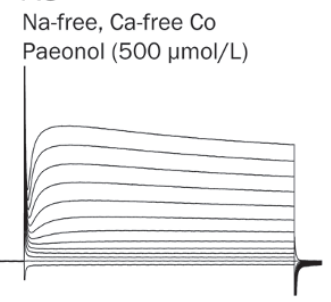

A4

Na-free, Ca-free Co Paeonol (1.5 mmol/L)

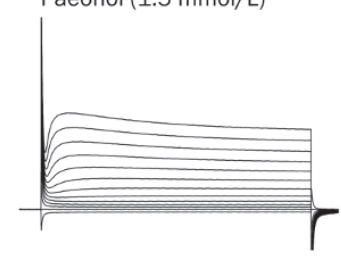

B2

Na-free, Ca-free Co

TEA (50 mmol/L), Paeonol (500 $\mu \mathrm{mol} / \mathrm{L})$
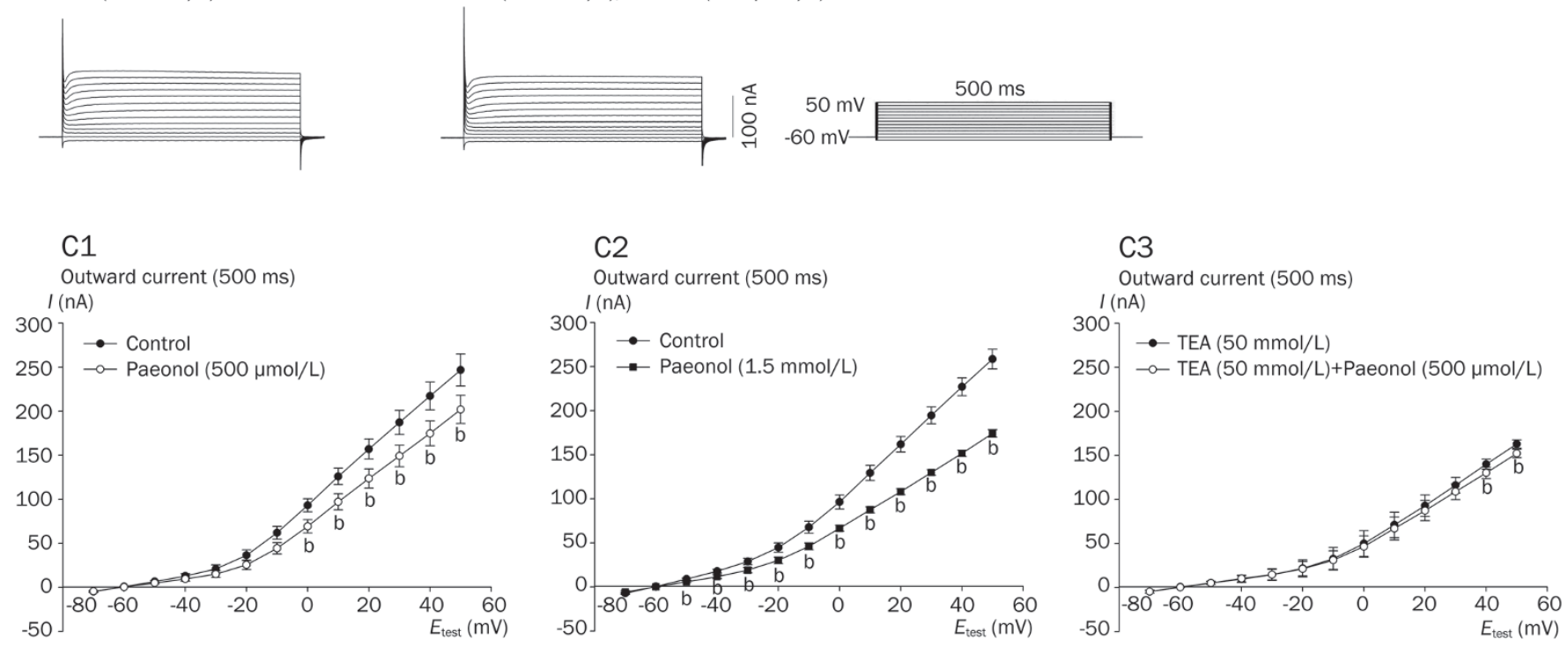

Figure 6. Effects of paeonol on steady-state outward currents of the RP4 neuron in $\mathrm{Na}^{+}$-free and $\mathrm{Co}^{2+}$-substituted $\mathrm{Ca}^{2+}$-free saline in the absence and presence of TEA $(50 \mathrm{mmol} / \mathrm{L})$. A and B were recorded from two different RP4 neurons. Currents were elicited by 500 -ms-long command steps from holding potentials of $-60 \mathrm{mV}$ to test potentials (ie, from -70 to $50 \mathrm{mV}$ at intervals of $10 \mathrm{mV}$ ). A1: Control; steady-state outward currents of the RP4 neuron in $\mathrm{Na}^{+}$-free and $\mathrm{Co}^{2+}$-substituted $\mathrm{Ca}^{2+}$-free saline. A2, A3 and A4: 20 min after administration of paeonol $150 \mu \mathrm{mol} / \mathrm{L}, 500 \mu \mathrm{mol} / \mathrm{L}$ and 1.5 $\mathrm{mmol} / \mathrm{L}$, respectively. B1: Steady-state outward currents of the RP4 neuron in TEA (50 mmol/L)-containing $\mathrm{Na}^{+}$-free and $\mathrm{Co}^{2+}$-substituted $\mathrm{Ca}^{2+}$-free saline. B2: $20 \mathrm{~min}$ after administration of paeonol (500 $\mu \mathrm{mol} / \mathrm{L})$, from B1. C1 and C2: Effects of paeonol (500 $\mu \mathrm{mol} / \mathrm{L}$ and $1.5 \mathrm{mmol} / \mathrm{L})$ on the currentvoltage relationships of the steady-state outward currents measured at $500 \mathrm{~ms}$ of the RP4 neuron in $\mathrm{Co}^{2+}$-substituted $\mathrm{Ca}^{2+}$-free and $\mathrm{Na}^{+}$-free solution, respectively. The closed circle $(\bullet)$ in $\mathrm{C} 1$ and $\mathrm{C} 2$ represents the $I-V$ relationship before paeonol $(500 \mu \mathrm{mol} / \mathrm{L})$ application. The open circle $(0)$ in $\mathrm{C} 1$ and closed square ( $\mathbf{m})$ in $\mathrm{C} 2$ represent the $I-V$ relationship at $20 \mathrm{~min}$ after paeonol $(500 \mu \mathrm{mol} / \mathrm{L}$ and $1.5 \mathrm{mmol} / \mathrm{L})$ application, respectively $\left({ }^{\mathrm{b}} P<0.05 \mathrm{vs}\right.$ control, $n=5)$. C3: Effects of paeonol $(500 \mu \mathrm{mol} / \mathrm{L})$ on the current-voltage relationships of the steady-state outward currents measured at $500 \mathrm{~ms}$ of the RP4 neuron in TEA (50 mmol/L)-containing $\mathrm{Co}^{2+}$-substituted $\mathrm{Ca}^{2+}$-free and $\mathrm{Na}^{+}$-free solution. The closed circle $(\bullet)$ and open circle $(0)$ in $\mathrm{C} 3$ represent the $I-V$ relationship before and at $20 \mathrm{~min}$ after paeonol $(500 \mu \mathrm{mol} / \mathrm{L})$ application, respectively $\left({ }^{\mathrm{b}} P<0.05 \mathrm{vs}\right.$ the data in TEA $\left.50 \mathrm{mmol} / \mathrm{L}\right)$. However, when neurons were pretreated with TEA, paeonol was less effective at decreasing the outward current.

significantly decreased the current under test potentials ranging from $-50 \mathrm{mV}$ to $50 \mathrm{mV}$; the current amplitude measured at $500 \mathrm{~ms}$ was reduced by $84.4 \pm 0.7 \mathrm{nA}$ (by $32.3 \% \pm 2.6 \%$ vs controls, paired $t$-test, $P<0.05, n=5$ ) at a test potential of $50 \mathrm{mV}$.

The effects of paeonol $(500 \mu \mathrm{mol} / \mathrm{L})$ on the steady-state outward current in $\mathrm{Na}^{+}$-free and $\mathrm{Co}^{2+}$-substituted $\mathrm{Ca}^{2+}$-free solution containing TEA $(50 \mathrm{mmol} / \mathrm{L})$ are shown in Figure 6B. The corresponding amplitudes of the steady-state outward current were measured after $500 \mathrm{~ms}$ of the outward current, and the steady-state current-voltage $(I-V)$ relationships are shown in Figure 6C3. After a 20-min application of paeonol $(500 \mu \mathrm{mol} / \mathrm{L})$, the currents at test potentials between -50 and
$30 \mathrm{mV}$ were not significantly affected, but the currents at test potentials of 40 and $50 \mathrm{mV}$ were slightly decreased. The current amplitude at $500 \mathrm{~ms}$ was reduced by $10.7 \pm 0.5 \mathrm{nA}$ (by $6.6 \% \pm 0.4 \%$ vs controls, paired $t$-test, $P<0.05, n=4)$ at a test potential of $50 \mathrm{mV}$.

Paeonol $(500 \mu \mathrm{mol} / \mathrm{L})$ decreased the steady-state current in a $\mathrm{Na}^{+}$-free and $\mathrm{Co}^{2+}$-substituted $\mathrm{Ca}^{2+}$-free solution, but only slightly decreased the steady-state current in RP4 neurons pretreated with TEA $(50 \mathrm{mmol} / \mathrm{L})$ (Figure 6). These data suggest that the paeonol-elicited decrease in the steady-state current in the $\mathrm{Na}^{+}$-free and $\mathrm{Co}^{2+}$-substituted $\mathrm{Ca}^{2+}$-free solution is mainly due to a decrease in the TEA-sensitive current. 
Effects of 4-AP, TEA and charybdotoxin on the spontaneous action potentials of the RP4 neuron

To elucidate the role of $I_{\mathrm{KD}}, I_{\mathrm{A}}$, and $I_{\mathrm{K}(\mathrm{Ca})}$ in the generation of the action potential bursts elicited by paeonol, we tested the effects of 4-AP, TEA and charybdotoxin on spontaneous action potentials. An example of the effects of $4-\mathrm{AP}(5 \mathrm{mmol} / \mathrm{L})$ is shown in Figure 7B. Application of 4-AP, an inhibitor of $I_{\mathrm{A}}^{[24]}$, failed to elicit action potential bursts. Table 1 details the RMPs, frequencies and amplitudes of spontaneously generated action potentials after a $40-$ min treatment with 4 -AP (5 $\mathrm{mmol} / \mathrm{L})$.

TEA (50 mmol/L) elicited bursts of action potentials in the RP4 neurons, as shown in Table 1. An example of the effects of TEA on the spontaneous firing of action potentials is shown
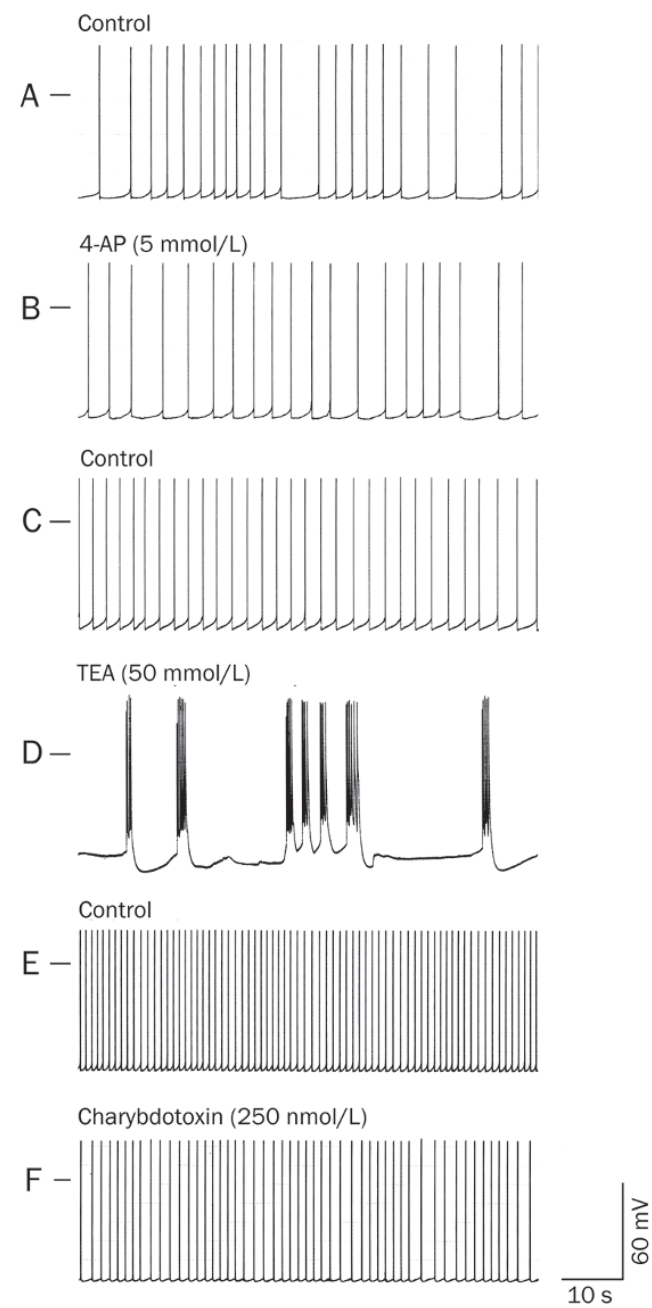

Figure 7. Effects of 4-AP ( $5 \mathrm{mmol} / \mathrm{L})$, TEA $(50 \mathrm{mmol} / \mathrm{L})$ and charybdotoxin $(250 \mathrm{nmol} / \mathrm{L})$ on spontaneous action potentials of the RP4 neuron. A and $\mathrm{B}, \mathrm{C}$, and $\mathrm{D}, \mathrm{E}$, and $\mathrm{F}$ were recorded from 3 different RP4 neurons. A, C, and $\mathrm{E}$ : Control; the spontaneous action potentials of the RP4 neuron. B, D, and $\mathrm{F}$ : The potentials at $40 \mathrm{~min}$ after perfusion with $4-\mathrm{AP}(5 \mathrm{mmol} / \mathrm{L})$, TEA $(50 \mathrm{mmol} / \mathrm{L})$ and charybdotoxin $(250 \mathrm{nmol} / \mathrm{L})$, respectively. The upper left-hand horizontal bar indicates the membrane potential at $0 \mathrm{mV}$. Note that while action potential bursts were not elicited by 4-AP $(5 \mathrm{mmol} / \mathrm{L})$ or charybdotoxin $(250 \mathrm{nmol} / \mathrm{L})$, they were elicited by TEA $(50 \mathrm{mmol} / \mathrm{L})$. in Figure 7D.

Charybdotoxin is a $I_{\mathrm{K}(\mathrm{Ca})}$ inhibitor and reportedly inhibits $I_{\mathrm{K}(\mathrm{Ca})}$ in the Aplysia neuron at concentrations between 100 $\mathrm{nmol} / \mathrm{L}$ and $300 \mathrm{nmol} / \mathrm{L}^{[25]}$. We therefore treated RP4 neurons with $250 \mathrm{nmol} / \mathrm{L}$ of charybdotoxin. After $40 \mathrm{~min}$, the RMPs, the frequencies and amplitudes of spontaneously generated action potentials remained unchanged from baseline. No bursting activity of potentials was observed (Figure 7F).

\section{Effects of TEA on paeonol-elicited action potential bursts}

To test whether the $I_{\mathrm{KD}}$ is involved in the generation of action potential bursts elicited by paeonol $(500 \mu \mathrm{mol} / \mathrm{L})$, we assessed the effects of TEA ( $5 \mathrm{mmol} / \mathrm{L})$, an $I_{\mathrm{KD}}$ blocker. As shown in Table 1 and Figure 8, TEA ( $5 \mathrm{mmol} / \mathrm{L})$ reduced the frequency of action potentials but failed to elicit action potential bursts.

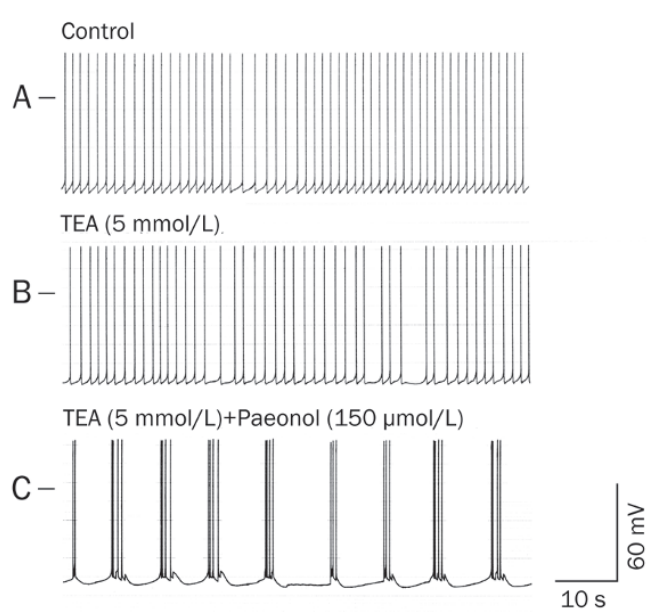

Figure 8. Effects of co-application of TEA ( $5 \mathrm{mmol} / \mathrm{L}$ ) plus paeonol (150 $\mu \mathrm{mol} / \mathrm{L}$ ) in the RP4 neuron. (A) Control; spontaneous action potentials of the RP4 neuron. (B) Potentials at $30 \mathrm{~min}$ after administration of TEA (5 $\mathrm{mmol} / \mathrm{L}$ ). (C) Potentials at $20 \mathrm{~min}$ after further incubation with paeonol $(150 \mu \mathrm{mol} / \mathrm{L})$ and TEA $(5 \mathrm{mmol} / \mathrm{L})$. The left-hand horizontal bar indicates the membrane potential at $0 \mathrm{mV}$. Note that co-application of TEA ( 5 $\mathrm{mmol} / \mathrm{L})$ plus paeonol $(150 \mu \mathrm{mol} / \mathrm{L})$ elicited action potential bursts.

The facilitative effects of TEA were tested in RP4 neurons pretreated with a low concentration of paeonol $(150 \mu \mathrm{mol} / \mathrm{L})$ (Figure 8). Whereas paeonol at $150 \mu \mathrm{mol} / \mathrm{L}$ alone failed to elicit action potential bursts, the coadministration of paeonol $(150 \mu \mathrm{mol} / \mathrm{L})$ with TEA $(5 \mathrm{mmol} / \mathrm{L})$ elicited action potential bursts after $20 \mathrm{~min}$.

\section{Discussion}

This study investigated the effects of paeonol on the electrophysiological behavior of the central RP4 neuron in the giant African snail (Achatina fulica Ferussac). The neuron exhibited spontaneous regular firing of action potentials. No bursts of action potential activity were found in control RP4 neurons, whereas extracellular application of paeonol $(500 \mu \mathrm{mol} / \mathrm{L}$ and $1.5 \mathrm{mmol} / \mathrm{L}$ ) reversibly elicited bursts of action potential spikes in a dose-dependent manner (Figure 1). The highest 
concentration of paeonol $(1.5 \mathrm{mmol} / \mathrm{L})$ elicited more remarkable bursting behavior patterns compared with those observed after $500 \mu \mathrm{mol} / \mathrm{L}$. The bursting pattern elicited by paeonol (500 $\mu \mathrm{mol} / \mathrm{L})$ was not abolished after continuous perfusion with $\mathrm{Co}^{2+}$-substituted $\mathrm{Ca}^{2+}$-free solution (Figure 2B2), although the amplitudes of the action potentials were reduced. These findings suggest that paeonol-elicited bursts of potential firing are not directly associated with calcium fluxes of the neuron.

It has been suggested that both PKA and PKC play a key role in the plasticity of the nervous system in vertebrates and invertebrates. PKA and PKC modulate the function of ion channels $^{[26-28]}$. In previous studies, we found that PKA and PKC activity were associated with the generation of action potential bursts in the central RP4 snail neuron ${ }^{[16,17]}$.

The PKA inhibitor KT-5720 is used at concentrations of approximately $10 \mu \mathrm{mol} / \mathrm{L}$ as a research tool in snail and Aplysia neurons ${ }^{[12,29]}$. The bisindolylmaleimide Ro 31-8220 is a structurally-related staurosporine analog, which acts as an ATP-competitive inhibitor of PKC and has been used extensively for studying the role of PKC in cell signaling ${ }^{[22]}$. Recently, Ro 31-8220 (1-10 $\mathrm{mmol} / \mathrm{L})^{[22]}$ has been used in snail ${ }^{[30]}$ and Aplysia neurons ${ }^{[27]}$. In our previous work, pretreatment with KT-5720 (10 $\mu \mathrm{mol} / \mathrm{L})$ and Ro 31-8220 (20 $\mu \mathrm{mol} / \mathrm{L})$ prevented the induction of action potential bursts elicited by methamphetamine (METH) and 3,4-methylenedioxymethamphetamine (MDMA), respectively ${ }^{[16]}$. In the present study, the action potential bursts elicited by paeonol $(500 \mu \mathrm{mol} / \mathrm{L})$ were not affected by KT-5720 (10 $\mu \mathrm{mol} / \mathrm{L}$; Figure 3) or Ro 31-8220 (20 $\mathrm{mmol} / \mathrm{L}$; Figure 3 ). These results suggest that the action potential bursts elicited by paeonol are not associated with PKA and PKC activity.

Ionic currents play an important role in the firing of action potential bursts, as seen in the neurons of Aplysia california ${ }^{[31]}$, Euhadra peliomphala ${ }^{[32]}$, and Drosophila ${ }^{[33]}$. To understand the mechanism underlying paeonol-elicited potential bursts, the effects of paeonol on ionic currents were investigated at a concentration of $500 \mu \mathrm{mol} / \mathrm{L}$. As shown in Figure 4, paeonol had no remarkable effects on the total inward currents.

In the RP4 neuron, the $I_{\mathrm{A}}$ is sensitive to $4-\mathrm{AP}$, the $I_{\mathrm{KD}}$ is sensitive to TEA, and the $I_{\mathrm{K}(\mathrm{Ca})}$ is sensitive to extracellular $\mathrm{Co}^{2+}$ ions $^{[13]}$. These findings are consistent with other research involving snail or Aplysia neurons ${ }^{[19,34,35]}$.

The measurement of the $I_{\mathrm{A}}$ followed Thompson's method ${ }^{[19]}$. The currents were elicited by $200 \mathrm{~ms}$ test potentials of -60 $\mathrm{mV},-50,-40$, and $-30 \mathrm{mV}$ from a holding potential of -100 $\mathrm{mV}$. At $20 \mathrm{~min}$ after paeonol application $(500 \mu \mathrm{mol} / \mathrm{L}$ and 1.5 $\mathrm{mmol} / \mathrm{L}$ ), the peak $I_{\mathrm{A}}$ current was decreased (Figure 5). The $I_{\mathrm{A}}$ current was completely abolished if the bath solution was infused with 4-AP (5 mmol/L) for $20 \mathrm{~min}$. Notably, perfusion with 4-AP ( $5 \mathrm{mmol} / \mathrm{L})$ elicited no bursts of action potentials in the RP4 neuron (Figure 7B), a finding that is consistent with our previous study ${ }^{[13]}$. These results suggest that the effects of paeonol on the $I_{\mathrm{A}}$ current may not be directly related to its effects on bursts of action potentials.

To measure the $I_{\mathrm{KD}}$ current, the steady-state outward current was elicited with 500-ms-long voltage clamp steps in a
$\mathrm{Na}^{+}$-free and $\mathrm{Co}^{2+}$-substituted $\mathrm{Ca}^{2+}$-free solution ${ }^{[36]}$. Under this condition, the $I_{\mathrm{K}(\mathrm{Ca})}, I_{\mathrm{Ca}}$ and $I_{\mathrm{Na}}$ were removed. To identify the $I_{\mathrm{KD}}$, TEA was applied. The amplitude at $500 \mathrm{~ms}$ of outward current was significantly reduced after perfusion with TEA (50 $\mathrm{mmol} / \mathrm{L})$. The sensitivity of the outward current to TEA indicated that this is a type of $I_{\mathrm{KD}}$. Notably, a sustained residual current was insensitive to TEA ${ }^{[19]}$.

We also sought to determine whether paeonol affected the $I_{\mathrm{KD}}$. Our results indicate that paeonol at $500 \mu \mathrm{mol} / \mathrm{L}$ decreased the steady-state current in $\mathrm{Na}^{+}$-free and $\mathrm{Co}^{2+}$-substituted $\mathrm{Ca}^{2+}$-free solution but only slightly decreased the steadystate current when the RP4 neurons were pretreated with TEA $50 \mathrm{mmol} / \mathrm{L}$ (Figure 6). This result suggests that paeonol decreases the TEA-sensitive $I_{\mathrm{KD}}$. In our experiments, paeonol significantly decreased the outward current, including the $I_{\mathrm{A}}$ and the $I_{\mathrm{KD}}$, but did not affect the total inward current. It may be that paeonol has greater potency on potassium currents in this preparation.

To further test whether inhibition of $I_{\mathrm{KD}}$ is involved in the generation of action potential bursts, we examined the effects of TEA on action potential bursting. As in our previous work, we found that TEA elicited action potential bursts at a concentration of $50 \mathrm{mmol} / \mathrm{L}$ (Figure 7D), but not at $5 \mathrm{mmol} / \mathrm{L}$ (Figure $8 \mathrm{~B})^{[13]}$. In the present study, paeonol $(150 \mu \mathrm{mol} / \mathrm{L})$ alone failed to elicit action potential bursts (Figure 1B), whereas its co-application with TEA (5 mmol/L) did elicit action potential bursts (Figure 8C). These data suggest that inhibition of $I_{\mathrm{KD}}$ facilitates the effects of paeonol; the TEA-sensitive $I_{\mathrm{KD}}$ helps to generate paeonol-elicited action potential bursts.

The $I_{\mathrm{K}(\mathrm{Ca})}$ current plays an important role in the regulation of neuronal excitability ${ }^{[37]}$. To further clarify the role of the $I_{\mathrm{K}(\mathrm{Ca})}$ current in the generation of action potential bursts, we tested the effects of charybdotoxin; this agent failed to elicit action potential bursts (Figure 7F). Notably, perfusion with $\mathrm{Co}^{2+}$ substituted $\mathrm{Ca}^{2+}$-free solution failed to elicit action potential bursts in the RP4 neuron (Figure 2). These findings suggest that the $I_{\mathrm{K}(\mathrm{Ca})}$ current may not be involved in the generation of action potential bursts.

In animal models, paeonol showed anxiolytic-like effects at a dose of $17.5 \mathrm{mg} / \mathrm{kg}$ (po), and at doses of 50 and $100 \mathrm{mg} / \mathrm{kg}$ (po) in mice successfully reduced oxidative stress, cognitive impairment and neurotoxicity induced by $D$-galactose (50 $\left.\mathrm{mg} \cdot \mathrm{kg}^{-1} \cdot \mathrm{d}^{-1}\right)^{[9,38]}$. At doses of 30 and $100 \mathrm{mg} / \mathrm{kg}(i p)$, paeonol inhibited carrageenan-evoked thermal hyperalgesia in rats ${ }^{[39]}$. In mice, maximum plasma levels were around $16.3 \mu \mathrm{mol} / \mathrm{L}$ after oral dosing with $20 \mathrm{mg} / \mathrm{kg}$ paeonol ${ }^{[40]}$.

In vitro studies have used varying concentrations. At concentrations up to $500 \mu \mathrm{g} / \mathrm{mL}$ (around $3 \mathrm{mmol} / \mathrm{L}$ ), paeonol has not shown any cytotoxicity in normal human endothelial cells as assessed by a trypan blue dye exclusion test. In the concentration range of 125 to $500 \mu \mathrm{g} / \mathrm{mL}$ (around $750 \mu \mathrm{mol} / \mathrm{L}$ to 3 $\mathrm{mmol} / \mathrm{L})$, paeonol significantly inhibited proliferation of basic fibroblast growth factor (bFGF)-stimulated human umbilical vein endothelial cells (HUVECs) ${ }^{[41]}$. At concentrations ranging from $24 \mu \mathrm{mol} / \mathrm{L}$ to $1.5 \mathrm{mmol} / \mathrm{L}$, paeonol inhibited cell proliferation in HT-29 cells ${ }^{[42]}$ and protected rat neurons from 
oxygen-glucose deprivation-induced injury at $0.2-5 \mu \mathrm{mol} / \mathrm{L}^{[8]}$. In addition, paeonol $(15.63-62.5 \mathrm{mg} / \mathrm{L})$ in combination with cisplatin has shown a synergistic growth-inhibitory and apoptosis-inducing effect in two human hepatoma cell lines ${ }^{[43]}$.

In investigations seeking clarification of how paeonol affects ionic function in excitable tissue, concentrations of $160 \mu \mathrm{mol} / \mathrm{L}$ and $640 \mu \mathrm{mol} / \mathrm{L}$ successfully decreased the action potential upstroke phase in guinea pig ventricular cells ${ }^{[7]}$. At concentrations ranging from $25 \mu \mathrm{g} / \mathrm{mL}$ to $400 \mu \mathrm{g} / \mathrm{mL}(150 \mu \mathrm{mol} / \mathrm{L}-2.4$ $\mathrm{mmol} / \mathrm{L}$ ), paeonol inhibited the delayed outward $\mathrm{K}^{+}$current and, to a lesser extent, the $I_{\mathrm{Na}}$ in NG108-15 cells ${ }^{[44]}$. The data from our present study indicate that paeonol at a concentration of $\geq 500 \mu \mathrm{mol} / \mathrm{L}$ reversibly elicits action potential bursts of the central RP4 neuron. The concentration used in the present study may be higher than that of the plasma concentration in vivo and may be associated with toxic effects.

An identifiable unit of epileptiform activity in the mammalian central nervous system (CNS) is the interictal spike. The intracellular correlate of the interictal spike is an overt depolarization, termed the paroxysmal depolarizing shift (PDS), that results in the initiation of a high-frequency burst of action potentials followed by a period of hyperpolarization $^{[45-47]}$. Research has revealed that convulsants, such as pentylenetetrazol (PTZ), induce bursts of action potentials in snail central neurons ${ }^{[32,48,49]}$, a response that closely resembles the PTZ-induced PDS in the cerebral cortical neurons of mammals ${ }^{[50]}$. In our previous studies, CNS stimulants, such as $d$-amphetamine, cocaine and methamphetamine, elicited in vitro action potential bursts in the central RP4 neuron of the African snail, Achatina fulica Ferussac ${ }^{[13,15,16]}$. Interestingly, high doses of these substances induce convulsions in animals and in humans. The present study demonstrated that paeonol at $500 \mu \mathrm{mol} / \mathrm{L}$ induced bursts of action potential in neurons. Our data indicate that paeonol at high doses may have a proepileptic effect. Patients should be closely supervised if the Moutan cortex of Paeonia suffruticosa Andrews (MC) is combined with a CNS stimulant.

\section{Conclusion}

The present study aimed to elucidate the effects of paeonol on membrane potentials and ionic currents in the central RP4 neuron using the conventional two-electrode voltage clamp technique. Our results indicate that paeonol elicits a bursting firing pattern in action potentials that is closely related to the inhibitory effects on the $I_{\mathrm{KD}}$.

\section{Acknowledgements}

We are grateful to Ms Iona MacDonald, a native English speaker, for checking the English in this paper. This work was supported by grants NSC 98-2320-B-039-016 and 98-2622-B039-001-CC3, issued by the National Science Council, Taipei, Taiwan, China.

\section{Author contribution}

Yi-hung CHEN: collection and assembly of data, manuscript writing; Pei-lin LIN: conception and design; Hui-yu HSU: col- lection and assembly of data; Ya-ting WU: revision of the manuscript; Dah-yuu LU: conception and design; Han-yin YANG: collection and assembly of data; Shiang-suo HUANG: collection and assembly of data; Ching-liang HSIEH: conception and design; Jaung-geng LIN: conception and design, manuscript writing.

\section{References}

1 Hirai A, Terano T, Hamazaki T, Sajiki J, Saito H, Tahara K, et al. Studies on the mechanism of antiaggregatory effect of Moutan Cortex. Thromb Res 1983; 31: 29-40.

2 Lin HC, Ding HY, Ko FN, Teng CM, Wu YC. Aggregation inhibitory activity of minor acetophenones from Paeonia species. Planta Med 1999; 65: 595-9.

3 Harada M, Yamashita A, Aburada M. Pharmacological studies on the root bark of Paeonia moutan. II. Anti-inflammatory effect, preventive effect on stress-induced gastric erosion, inhibitory effect on gastric juice secretion and other effects of paeonol. Yakugaku Zasshi 1972; 92: 750-6.

4 Zhang HY, Ge N, Zhang ZY. Theoretical elucidation of activity differences of five phenolic antioxidants. Acta Pharmacol Sin 1999; 20: 363-6.

5 Zhang WG, Zhang ZS. Anti-ischemia reperfusion damage and antilipid peroxidation effects of paeonol in rat heart. Yao Xue Xue Bao 1994; 29: 145-8.

6 Zhang GQ, Hao XM, Zhou PA, Wu CH. Effect of paeonol on L-type calcium channel in rat ventricular myocytes. Methods Find Exp Clin Pharmacol 2003; 25: 281-5.

7 Ma YL, Bates S, Gurney AM. The effects of paeonol on the electrophysiological properties of cardiac ventricular myocytes. Eur J Pharmacol 2006; 545: 87-92.

8 Wu JB, Song NN, Wei XB, Guan HS, Zhang XM. Protective effects of paeonol on cultured rat hippocampal neurons against oxygen-glucose deprivation-induced injury. J Neurol Sci 2008; 264: 50-5.

9 Zhong SZ, Ge QH, Qu R, Li Q, Ma SP. Paeonol attenuates neurotoxicity and ameliorates cognitive impairment induced by d-galactose in ICR mice. J Neurol Sci 2009; 277: 58-64.

10 Kerkut GA, Lambert JD, Gayton RJ, Loker JE, Walder RJ. Mapping of nerve cells in the suboesophageal ganglia of Helix aspersa. Comp Biochem Physiol A Comp Physiol 1975; 50: 1-25.

11 Takeuchi H, Araki Y, Emaduddin M, Zhang W, Han XY, Salunga TL, et al. Identifiable Achatina giant neurones: their localizations in ganglia, axonal pathways and pharmacological features. Gen Pharmacol 1996; 27: 3-32.

$12 \mathrm{Lin} \mathrm{CH}$, Tsai MC. The modulation effects of d-amphetamine and procaine on the spontaneously generated action potentials in the central neuron of snail, Achatina fulica Ferussac. Comp Biochem Physiol C Toxicol Pharmacol 2005; 141: 58-68.

13 Chen $\mathrm{YH}$, Lin CH, Lin PL, Tsai MC. Cocaine elicits action potential bursts in a central snail neuron: the role of delayed rectifying $\mathrm{K}^{+}$ current. Neuroscience 2006; 138: 257-80.

14 Onizuka S, Kasaba T, Takasaki M. The effect of lidocaine on cholinergic neurotransmission in an identified reconstructed synapse. Anesth Analg 2008; 107: 1236-42.

15 Tsai MC, Chen YH. Bursting firing of action potentials in central snail neurons elicited by $d$-amphetamine: role of the electrogenic sodium pump. Comp Biochem Physiol C Pharmacol Toxicol Endocrinol 1995; 111: 131-41.

16 Lin PL, Tsai MC, Lu GL, Lu DY, Chuang CM, Yang HY, et al. Ecstasy and methamphetamine elicit action potential bursts via different 
mechanisms in a central snail neuron. Neurotoxicology 2010; 31: 26-41.

17 Tsai MC, Chen YH. (+/-)3,4-Methylenedioxyamphetamine elicits action potential bursts in a central snail neuron. Exp Neurol 2007; 203: 423-44.

18 Arvanov VL, Liou HH, Chang YC, Chen RC, Peng FC, Ling KH, et al. Interactions of anticholinesterases with Achatina fulica acetylcholine responses and electrogenic sodium pump. Neuroscience 1994; 62: 581-6.

19 Thompson SH. Three pharmacologically distinct potassium channels in molluscan neurones. J Physiol 1977; 265: 465-88.

20 Sun XP, Funase K, Takeuchi H. Ionic current of an identifiable giant neurone, d-RPLN, of an African giant snail (Achatina fulica Ferussac), measured under voltage clamping - II. Outward currents. Comp Biochem Physiol A Comp Physiol 1987; 88: 707-14.

21 Kim MS, Cheong YP, So HS, Lee KM, Son Y, Lee CS, et al. Regulation of cyclic AMP-dependent response element-binding protein (CREB) by the nociceptin/orphanin $\mathrm{FQ}$ in human dopaminergic SH-SY5Y cells. Biochem Biophys Res Commun 2002; 291: 663-8.

22 Beltman J, McCormick F, Cook SJ. The selective protein kinase C inhibitor, Ro-31-8220, inhibits mitogen-activated protein kinase phosphatase-1 (MKP-1) expression, induces c-Jun expression, and activates Jun N-terminal kinase. J Biol Chem 1996; 271: 27018-24.

23 Chen YH, Tsai MC. Action potential bursts in central snail neurons elicited by d-amphetamine: roles of ionic currents. Neuroscience 2000; 96: 237-48.

24 Bukanova JV, Solntseva El, Skrebitsky VG. Selective suppression of the slow-inactivating potassium currents by nootropics in molluscan neurons. Int J Neuropsychopharmacol 2002; 5: 229-37.

25 Hermann A, Erxleben C. Charybdotoxin selectively blocks small Caactivated K channels in Aplysia neurons. J Gen Physiol 1987; 90: $27-47$.

26 Conn PJ, Strong JA, Azhderian EM, Nairn AC, Greengard P, Kaczmarek LK. Protein kinase inhibitors selectively block phorbol ester- or forskolin-induced changes in excitability of Aplysia neurons. J Neurosci 1989; 9: 473-9.

27 Manseau F, Sossin WS, Castellucci VF. Long-term changes in excitability induced by protein kinase $\mathrm{C}$ activation in Aplysia sensory neurons. J Neurophysiol 1998; 79: 1210-8.

28 Su TR, Chen CH, Huang SJ, Lee CY, Su MC, Chen GH, et al. Functional study of the effect of phosphatase inhibitors on KCNQ4 channels expressed in Xenopus oocytes. Acta Pharmacol Sin 2009; 30: 12206.

29 Nakayama T, Harada N, Asano M, Nomura N, Saito T, Mishima A, et al. Atrial natriuretic peptide reduces ischemia/reperfusion-induced spinal cord injury in rats by enhancing sensory neuron activation. J Pharmacol Exp Ther 2007; 322: 582-90.

30 Nikitin VP, Kozyrev SA. Protein kinase $C$ is selectively involved in the mechanisms of long-term synaptic plasticity. Bull Exp Biol Med 2005; 139: 639-42.

31 Smith TG Jr, Barker JL, Gainer H. Requirements for bursting pacemaker potential activity in molluscan neurones. Nature 1975; 253 : 450-2.

32 Onozuka M, Kubo KY, Ozono S. The molecular mechanism underlying pentylenetetrazole-induced bursting activity in Euhadra neurons: involvement of protein phosphorylation. Comp Biochem Physiol C 1991; 100: 423-32.

33 Zhao ML, Wu CF. Alterations in frequency coding and activity dependence of excitability in cultured neurons of Drosophila memory mutants. J Neurosci 1997; 17: 2187-99.

34 Staras K, Gyori J, Kemenes G. Voltage-gated ionic currents in an identified modulatory cell type controlling molluscan feeding. Eur J Neurosci 2002; 15: 109-19.

35 Sakakibara M, Okuda F, Nomura K, Watanabe K, Meng H, Horikoshi $\mathrm{T}$, et al. Potassium currents in isolated statocyst neurons and RPeD1 in the pond snail, Lymnaea stagnalis. J Neurophysiol 2005; 94 : 3884-92.

36 Kraliz D, Singh S. Selective blockade of the delayed rectifier potassium current by tacrine in Drosophila. J Neurobiol 1997; 32: 1-10.

37 Latorre R, Oberhauser A, Labarca P, Alvarez O. Varieties of calciumactivated potassium channels. Annu Rev Physiol 1989; 51: 385-99.

38 Mi XJ, Chen SW, Wang WJ, Wang R, Zhang YJ, Li WJ, et al. Anxiolyticlike effect of paeonol in mice. Pharmacol Biochem Behav 2005; 81: 683-7.

39 Chou TC. Anti-inflammatory and analgesic effects of paeonol in carrageenan-evoked thermal hyperalgesia. Br J Pharmacol 2003; 139: 1146-52.

$40 \mathrm{Wu}$ X, Chen H, Chen X, Hu Z. Determination of paeonol in rat plasma by high-performance liquid chromatography and its application to pharmacokinetic studies following oral administration of Moutan cortex decoction. Biomed Chromatogr 2003; 17: 504-8.

41 Kim SA, Lee HJ, Ahn KS, Lee EO, Choi SH, Jung SJ, et al. Paeonol exerts anti-angiogenic and anti-metastatic activities through downmodulation of Akt activation and inactivation of matrix metalloproteinases. Biol Pharm Bull 2009; 32: 1142-7.

42 Ye JM, Deng T, Zhang JB. Influence of paeonol on expression of COX-2 and p27 in HT-29 cells. World J Gastroenterol 2009; 15: 4410-4.

43 Xu SP, Sun GP, Shen YX, Peng WR, Wang H, Wei W. Synergistic effect of combining paeonol and cisplatin on apoptotic induction of human hepatoma cell lines. Acta Pharmacol Sin 2007; 28: 869-78.

$44 \mathrm{Hu}$ Q, Shi YL. Inhibition of voltage-gated $\mathrm{K}^{+}, \mathrm{Na}^{+}$, and $\mathrm{Ca}^{2+}$ currents in neuroblastoma $\mathrm{x}$ glioma hybrid cells by paeonol. Sheng Li Xue Bao 1994; 46: 575-80.

45 McCormick DA, Contreras D. On the cellular and network bases of epileptic seizures. Annu Rev Physiol 2001; 63: 815-46.

46 Jefferys JG. Nonsynaptic modulation of neuronal activity in the brain: electric currents and extracellular ions. Physiol Rev 1995; 75: 689723.

47 Jefferys JG. Experimental neurobiology of epilepsies. Curr Opin Neurol 1994; 7: 113-22.

48 Onozuka M, Imai S, Sugaya E. Pentylenetetrazole-induced bursting activity and cellular protein phosphorylation in snail neurons. Brain Res 1986; 362: 33-9.

49 Sugaya E, Furuichi H, Takagi T, Kajiwara K, Komatsubara J. Intracellular calcium concentration during pentylenetetrazol-induced bursting activity in snail neurons. Brain Res 1987; 416: 183-6.

50 Szymusiak R, Shouse MN, McGinty D. Brainstem stimulation during sleep evokes abnormal rhythmic activity in thalamic neurons in feline penicillin epilepsy. Brain Res 1996; 713: 253-60. 